\title{
Accounting
}

homepage: www.GrowingScience.com/ac/ac.html

\section{The magnitude of the investment yield of sharia insurance in Indonesia}

\section{Mutia Ismail ${ }^{a^{*}}$}

${ }^{a}$ Faculty of Economics and Business, Accounting Department, Universitas Sumatera Utara, Medan, Indonesia

\section{H R O N I C L E}

\begin{tabular}{l}
\hline Article history: \\
Received: December 10, 2020 \\
Received in revised format: \\
January 32021 \\
Accepted: January 8, 2021 \\
Available online: \\
January 8, 2021 \\
\hline Keywords: \\
Dovish/hawkish sentiments \\
Investment yield \\
Gross Domestic Product \\
Population
\end{tabular}

\section{Introduction}

Economic growth is the development of activities in the economy that cause goods and services to be produced in society. Economic growth can be viewed as a long-term macroeconomic problem (Tarmizi et al., 2017, Banerjee \& Majumdar, 2018; Rethel, 2018; Shah et al., 2018). The ability of a country to produce goods and services can increase over time. This ability is a factor of production, which can experience an increase in output and quality (Abdulkader, 2005 \& Ahmed, 2010). The business world has continued to change and this has led the Islamic insurance business to also change with the times. Now is the time to move in a modern direction. This paper will cover topics ranging from concepts, models, and even to the media and ways of promotion that must be changed from conventional methods to new ways in the digital era of economists. Investment will increase the amount of capital goods (Suryomurti, 2018. Lian et al., 2020 and Savitska et al., 2020). The technology used is growing and the workforce increases as a result of population development. Experience and education also add to the skills of the workforce. Each economy must use a proportion of its national income to replace damaged capital goods (buildings. equipment. and materials). However, with the increase of the rate of the economy, new investments are also needed as additional capital stock. The economic growth depends on its natural resources, human capital, business, technology and so forth (Clarke \& Gholamshahi, 2018; Muda et al., 2018; Dong et al., 2020; Tejedo et al., 2020). However, economic growth is unlikely to occur as long as the social institutions, political conditions, and moral values in a nation are not supportive. For economic growth, the social institutions, cultural attitudes, moral values, and political and institutional conditions are non-economic factors. The political

* Corresponding author.

E-mail address: simanjorangasyiah@gmail.com (M. Ismail) 
stability, government economic policy, natural resources possessed, quantity and capability of labor, the availability of persistent entrepreneurs, and the ability to develop and use modern technology are some of the important factors affecting economic growth. The factors of economic growth are the talents, abilities, qualities, capacities and abilities, attitudes, customs, values, goals and motivations, as well as political and institutional structures. The income increase is measured in real terms, meaning that it is expressed in constant prices. This also simultaneously describes the remuneration operating in the area (land, capital, labor, and technology) which means that it can roughly illustrate the prosperity of the area. The prosperity of an area other than determined by added value created in the region is also determined by how much income flows out of the region or the flow of funds into the region. Regional economic growth is increasing in the era of regional autonomy. This is quite logical because in the era of regional autonomy, each region is vying to improve the prosperity of the community. Therefore, the discussion of the structure and factors of regional growth will be very important for local governments in determining the efforts that can be done to encourage economic growth in their regions. In general, for the global and domestic macroeconomic conditions, there are still various challenges and turmoil. From the global side, world economic growth is estimated to still not strengthen (Alqahtani, 2018; Faisal, 2018; Panagopoulos, 2018, Shaikh, 2018, Zafar et al., 2020; Erdogan et al., 2020). Economic improvement in the United States in quarter II-2016, which is referenced to the global economy grew below estimates and investment is still slowing down. Meanwhile, the European economy in 2016 was expected to grow moderately along with continued post-uncertainty Brexit and its impact on the confidence of market participants. Next, the economy in China was estimated to have limited growth by $6.5 \%$ in 2016 due to deceleration despite private sector investment and interest rates being maintained low.

Indonesia has great potential in the Islamic insurance industry in Asia and the world. This is because Indonesia is one of the countries in Asia that has high growth in developing the sharia insurance industry (Amron et al., 2018; Widodo, 2018; Panorama, 2018; Qoyum et al., 2018). In addition, the population is high and the accelerated high market expansion of the middle class provides more value for Indonesia to become an industrial source of Islamic insurance in Asia (Jiang, 2018). According to Business Monitor International (BMI), a world research institution headquartered in London, England, predicted that the industrial development of Islamic insurance in Indonesia will increase. Likewise, the Global Business Guide, an institution engaged in business promoters and this investment explained the insurance industry projections for Indonesia. This institution, based in Paris France, explained that insurance requires proper and accurate regulation so that it is capable of creating healthy competitiveness between the insurance industries. There are a number of things worries in the insurance industry and insurance market players in Indonesia. Among them is the growth of the market for some parties as regulations are less supportive and regulators in the financial sector are seen as minimal and require a great deal of changes. The amount of sharia insurance in Indonesia is increasing and the development of sharia law also continues to increase. With regulations from the government regarding the minimum insurance capital as well as plans for several sharia insurance companies to provide spin-off services according to the insurance law, we predict that for the coming years, the number of sharia insurance providers will continue to grow and ultimately have an impact on economic growth. In 2017, the growth of sharia insurance assets was $17 \%$ and the premium retreated by $20 \%$. In 2018 . The figure was lower than the $15 \%$ asset growth projection and $17 \%-18 \%$. The overview of sharia non-bank financial industry statistics from 2017 are as follows in Table 1.

Table 1

Indonesian sharia non-nank financial institutions statistics overview 2017

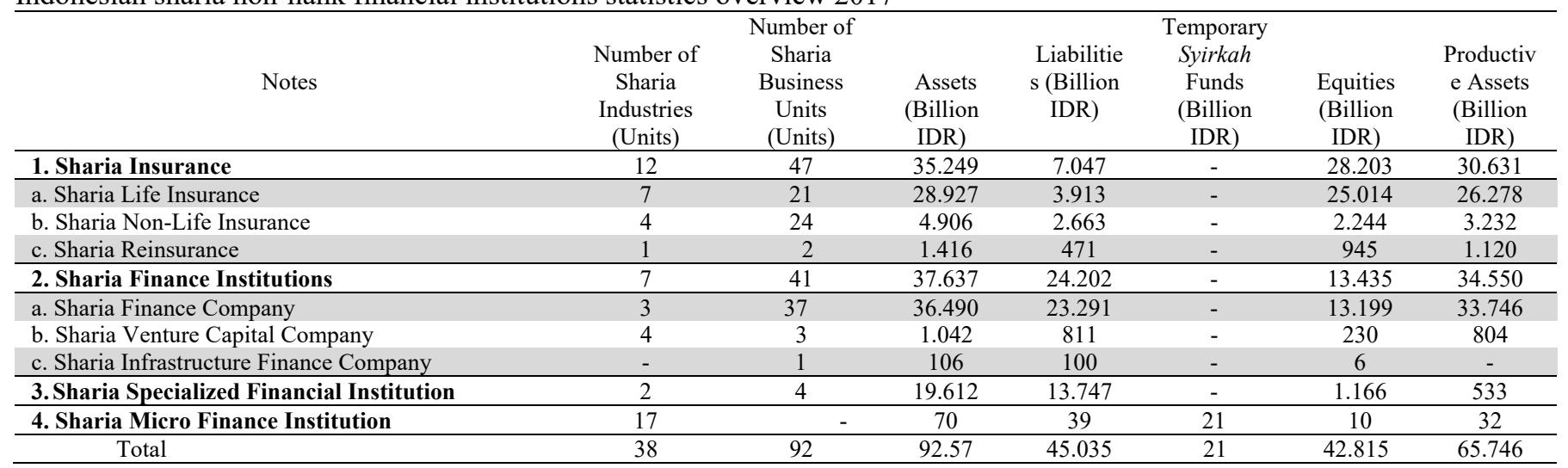

Sources: Financial Services Authority (OJK) Indonesia (2017).

Based on Table 1, the growth of sharia insurance assets in 2011-2015 fluctuated. This resulted in the market share for Islamic insurance assets fluctuating since 2011. From the data per July 2016, insurance growth assets sharia was decreased by $8 \%$. From the data we predicted that at the end of the year sharia insurance assets would only decrease or raise slightly. Investments are one component of growth supporting sharia insurance. The growth of sharia insurance investments fluctuated from 2011 until July 2016. The amount of sharia insurance investment in Indonesia at the end of 2015 was Rp, 23.1 trillion and, as of July 2016 , was 
predicted to be IDR 27.5 trillion. Researchers concluded that Islamic insurance investments experiencing average growth amounted to $31.6 \%$ (Karim Consulting Indonesia, 2017). Sharia insurance in Indonesia has grown rapidly. Sharia insurance business competition in Indonesia is increasingly crowded with the emergence of new players both from life insurance and loss insurance/general with the sharia principle. While Islamic insurance also experienced changes in composition, i.e., from the overall company in the form of a sharia business unit, there is one company that is fully focused on sharia insurance. We concluded that the amount of insurance sharia in Indonesia is relatively increasing and the development of sharia law continues to increase. With regulations from the government regarding the minimum insurance capital, as well as plans for several sharia insurance companies to do spin-offs according to the insurance law, we predict that, for the coming years, the number of sharia insurance companies will continue to grow. Domestic economic growth is not evenly distributed. From a sectoral perspective, economic recovery is supported by the financial sector and by agricultural services. Increased financial services are encouraged widening of the net interest margin (NIM) spread on credit interest rates and rates of deposit interest while improving the agricultural sector. The uncertainty of the economic recovery has an impact on the direction the monetary policies of the world's central banks and the increase in volatility in the financial market (Baber \& Zaruova, 2018; Barbu \& Boitan, 2018; El Ouadghiri \& Peillex, 2018; Elsner et al., 2018; Kail et al., 2018; Kesa, 2018; Samad, 2018; Corbet et al., 219; Arellano et al., 2020). The release of the developed country macroeconomic data, such as from the USA, becomes a sensitive issue and becomes a driving sentiment in market finance. The Fed's monetary policy is also an indicator of Indonesia's economic development, including the development of sharia insurance in Indonesia. When the expectations and sentiments are more "Hawkish", there is a flow of funds into the advanced economy (Mishra et al., 2018). As a result. the exchange rate and price of financial assets in emerging countries is depressed. This also happens in reverse, "Dovish" expectations and sentiments, followed by risk-on-market behavior, eventually push the flow of funds back to emerging countries (Bennani et al., 2018, Bonam, \& Goy, 2019; Baranowski et al., 2020). The dovish and hawkish sentiments of the Fed's monetary policy change the dynamics of the global financial markets. The result increases the risk in global financial markets due to the increased volatility, which directly impacts Indonesia. Related studies have examined the role of developing Islamic insurance, among others, including Ahmed et al., (2018); Albetairi et al. (2018); Alshammari et al., (2018); Benlagha \& Hemrit. (2018); Boakye. (2018); Effendi. (2018); Hasyim. (2018); Motsepe. (2018); Purwaningrat. (2018); Syed et al., (2018); Yas et al., (2018); Alam et al., (2019) and Siddiqui \& Yousaf (2020).

\section{Literature Review}

\subsection{Establishment of an Investment Portfolio}

The insurance industry as one of the financial institutions managing public funds in large especially life insurance is very dependent on the success of managing investments in an effort to realize the company's goals (Alhomaidi et al., 2018; Fuentes, 2018; Shetty \& Basri, 2018; Reyna \& Yu et al., 2018; Keenan et al., 2019; Buckle \& Thompson, 2020; Park \& Kim, 2020; Ismanto, 2018). Realizing this, financial management and investment experts attempt to develop measures that can be used to determine the risks. For example. whether or not an investment proposal is feasible or how successful an investment is in meeting the expected level of take. A portfolio is a collection of integrated forms of investment for the purpose of obtaining investment returns. The main purpose of establishing an investment portfolio is to obtain optimal results with minimal risk. If the investor is an institution as well as a life insurance company. Thus, the main objective of the investment portfolio is to obtain a high rate of return with a small level of risk to fulfill obligations to policyholders or for company growth.

\subsection{Diversifiable Risk}

The basic function of insurance is an effort to overcome uncertainty regarding specific losses for pure losses and not speculative losses so that the definition of risk can be given as an uncertainty regarding the occurrence or non-occurrence of an event (Darwish, 2018; Fonta et al., 2018; Sinha, 2018). Diversifiable risk (unsystematic risk) is a unique risk from a form of investment, namely business risk and financial risk (Abdi \& Cheluget, 2018; Suryawati \& Unsun, 2018; Eklund, 2019; Shileche et al., 2020). The stock price of a company will decrease if the performance of a company is not good enough to decrease the estimated profit which is a diversifiable risk.

\subsection{Non-diversifiable risk}

Non-diversifiable risk (systematic risk) is the risk of each form of investment. That is the risk that occurs due to war, inflation, international events, or due to politics (Sundh \& Juslin, 2018). The risk of market shifts in general will change the return of each security as a non-diversifiable risk (Abelson \& Dalton, 2018). Therefore, for a business to be successful and profitable, the business should be based on sound, wise, and careful decisions. The results that will be achieved by making sound and wise decisions will be real and durable.

\subsection{Differences in Takaful insurance vs. Conventional Insurance}

Islamic insurance appeared after the concept of general insurance. Takaful insurance appeared for the purpose of Islamizing general insurance, which is considered to have some deficiencies or even fraud, which is detrimental to the insurance participant (Mroueh \& Waal, 2018). The difference between takaful and conventional insurance is in Table 2. 
Table 2

Takaful (sharia) insurance vs. conventional insurance

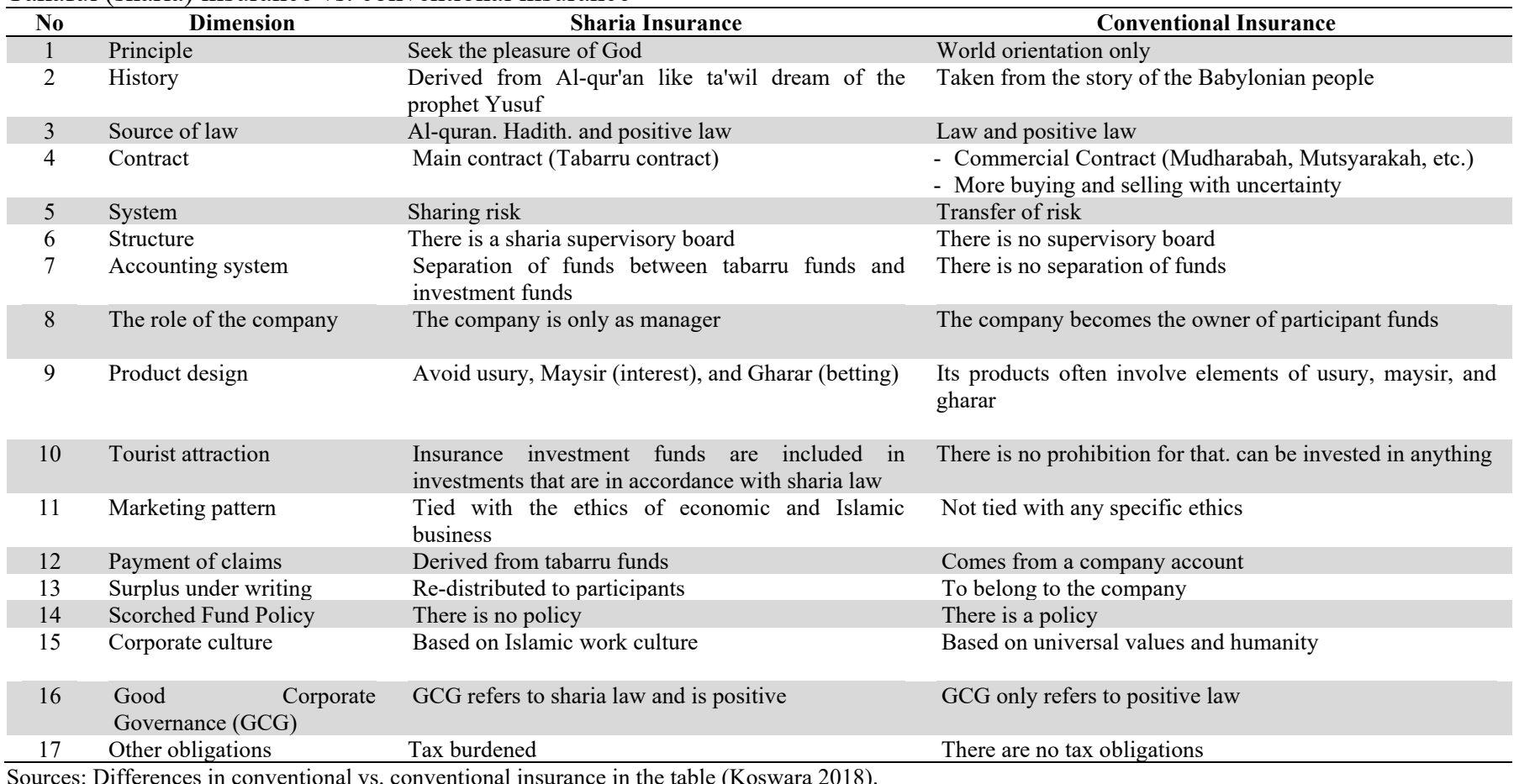

Sources: Differences in conventional vs. conventional insurance in the table (Koswara 2018).

Based on Table 2, in sharia insurance, everything has an overhaul as everything that is done in the management of this insurance must be based on the basic values of Islam from the al-qur'an, hadith, fatwa of ulama, and others.

\section{Methods}

The method of research used causal methods. The population taken was all sharia-based insurance companies that were under the supervision of the Financial Services Authority of the Republic of Indonesia. The number of sharia insurance and reinsurance companies reached 62 companies. The data used were secondary data sourced from the Financial Services Authority Republic of Indonesia in January 2015-September 2017. This study used data analysis methods including SmartPLS version 3.0 software. Smart-Partial Least Square (PLS) is a variant-based structural equation (SEM) analysis that can simultaneously test measurement models at once. Data processing was conducted using the SmartPLS software. PLS uses a bootstrapping method or random copying. Therefore, the assumption of normality will not be a problem for PLS.

Apart from being related to data normality, by doing bootstrapping, PLS does not require a minimum number of samples. Research that has a small sample can still use PLS. In PLS. the measurement model (outer model) is often called the outer relation or measurement mode, which defines how each indicator block relates to its latent variables. This Outer Model analysis specifies the relationship between latent variables and their indicators, or it can be said that the outer model defines how each indicator relates to its latent variables. Inner model testing or structural models were performed to investigate the relationship between latent constructs or variables, as seen from the R-square value of the research model and also by looking at the coefficient of the structural path. The higher the $\mathrm{R}^{2}$ value, the better the predictive model of the proposed research model. The formation of a path diagram in the PLS-SEM process is a visualization of the research conceptual framework so that it is easier to understand and learn. In addition. this path diagram will be tested through goodness of fit to see the suitability of the model with the existing reality.

\section{Result and Discussion}

\subsection{Result}

Based on the data the results of the descriptive statistics are in Table 3. Based on Table 3. the gross domestic product $\left(\mathrm{X}_{1}\right)$ had a minimum of 983 trillion and a maximum of IDR 12.407 trillion. The population in people had a minimum of 259 million people and a maximum of 262 million people. The investment yield variable had a minimum of IDR 23.134 billion and a maximum of IDR 33. 517 billion. This result was developed using SmartPLS as presented in Fig. 1 and Table 4. 
Table 3

Descriptive Statistics

\begin{tabular}{lccc} 
& Investment Yield & Gross Domestic Product & Population $\left(\mathrm{X}_{2}\right)$ \\
\hline Mean & $(\mathrm{Y})$ & 5988.0952 & 260.2857 \\
Std. Deviation & 28743.9524 & 3408.77102 & 1.52128 \\
Skewness & 3046.68901 & .224 & .311 \\
Std. Error of Skewness & -.208 & .501 & .501 \\
Kurtosis & .501 & -.965 & -2.115 \\
Std. Error of Kurtosis & -.896 & .972 & .972 \\
Minimum & .972 & 983.00 & 259.00 \\
Maximum & 23134.00 & 12407.00 & 262.00 \\
\hline Source: Data antys & 33517.00 & & 2 \\
\hline
\end{tabular}

Source : Data analysis (2018).

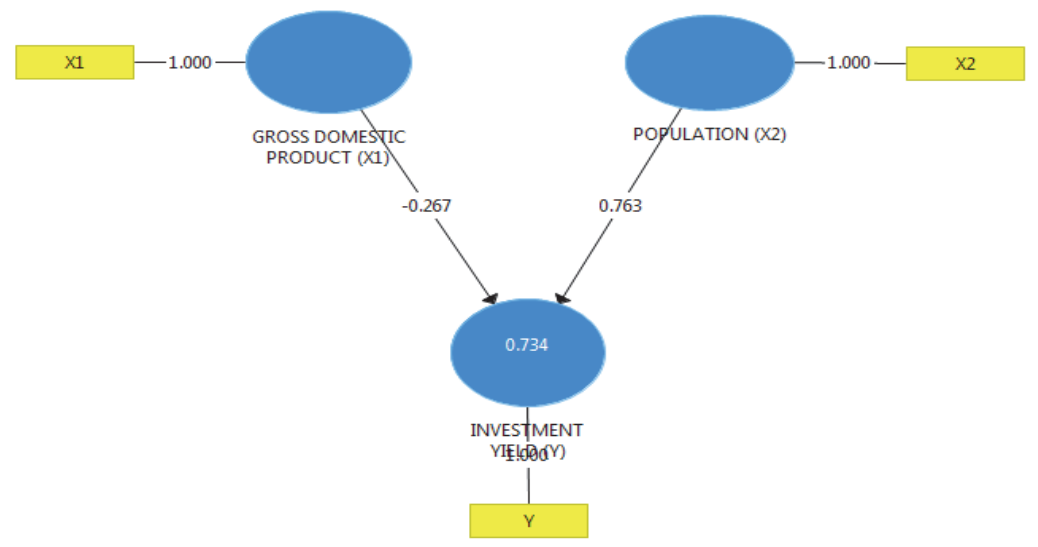

Sources : SmartPLS result (2018).

Fig. 1. Overall model with coefficient

The results are shown in Fig. 1 as the entire Model with coefficient. While the value of standard error (SE) was used to calculate the statistical $t$ value by dividing the regression coefficient with the standard error in the Table 4 is as follows.

Table 4

The result of bootstrapping

\begin{tabular}{|c|c|c|c|}
\hline & Standard Deviation & $t$ Statistics & $p$ Values \\
\hline Gross Domestic Product $\left(\mathrm{X}_{1}\right) \rightarrow$ Investment Yield $(\mathrm{Y})$ & 0.440 & 0.607 & 0.544 \\
\hline Population $\left(\mathrm{X}_{2}\right) \rightarrow$ Investment Yield $(\mathrm{Y})$ & 0.156 & 4.881 & 0.000 \\
\hline
\end{tabular}

Sources : SmartPLS result (2018).

In Table 4 , the population $\left(\mathrm{X}_{2}\right)$ produced a coefficient of less than 0.005 . The results show that population was a significant variable on investment yield. In addition. this can be proved by using SmartPLS output visually in Fig. 2.

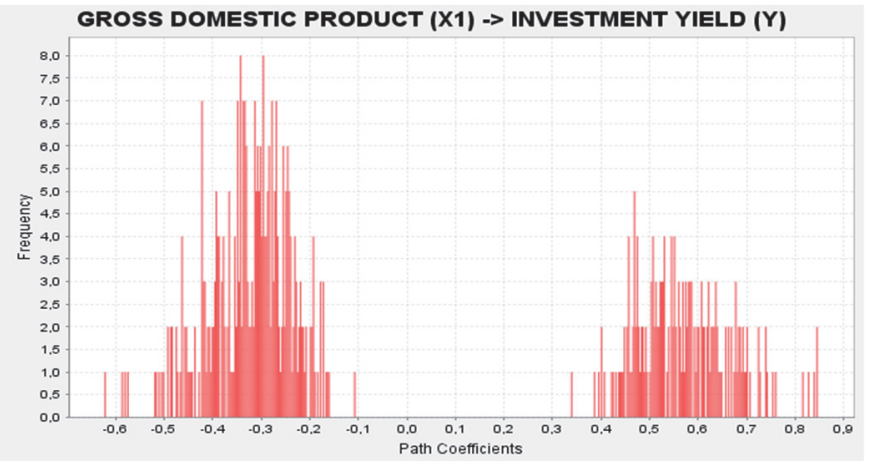

Fig. 2. Path Coefficient of the Gross Domestic Product Visually

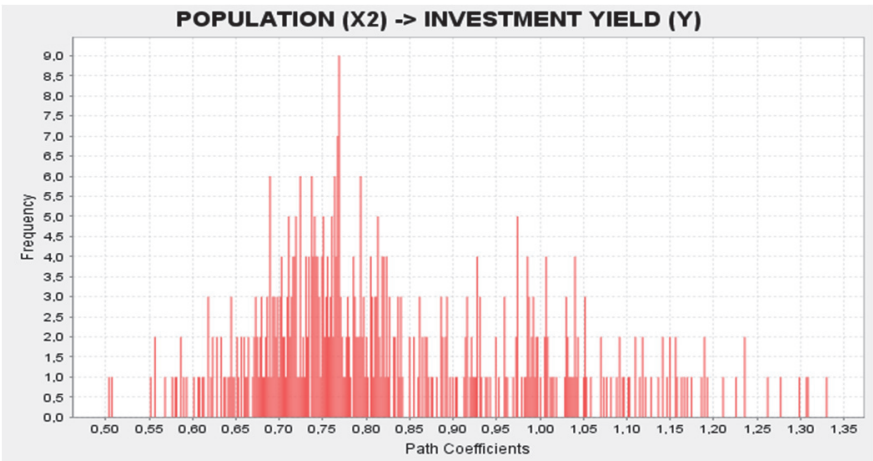

Fig. 3. Path Coefficient of the Population Visually

Sources : SmartPLS result (2018). 
Based on Fig. 2 in the Visual Path Coefficient Output. the meaning is the Gross Domestic Product variable is not dominant and uneven. The Population variable is dominant based on Fig. 3. The Visual Path Coefficient Output in Fig. 3 above shows that the population variable on the variable investment yield is dominant and evenly distributed. The Adjusted R-Square was generated as follows in Table 6.

Table 6

$\mathrm{R}^{2}$ Value

\begin{tabular}{lcc}
\hline & R Square & R Square Adjusted \\
\hline Investment Yield (Y) & 0.734 & 0.704 \\
\hline & & Sources : SmartPLS result (2018).
\end{tabular}

Based on Table 6, the structural model (inner model) predicts the causality relationship between variables. Through the bootstrapping process, statistical $t$ test parameters are obtained to predict the causality relationship. The structural model (inner model) is evaluated by looking at the percentage of variance explained by the $\mathrm{R}^{2}$ value for the dependent variable using size. Based on Table 6, the variation of the R-Square value is $73.4 \%$. Thus, the population provided a contribution to the investment yield of sharia insurance. The effect size (F square) is a measure of the practical significance of the research results in the form of a measure of the magnitude of a correlation or difference or the effect of a variable on another variable. This measure complements the results of the analysis information provided by the significance test in Fig. 4 as follows.

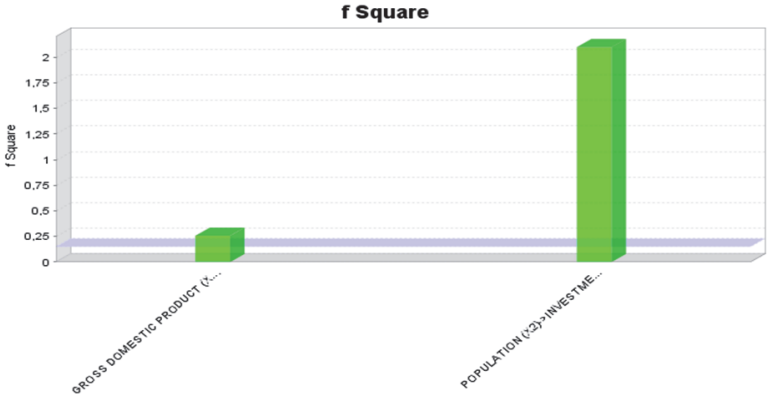

Fig. 4. F Square

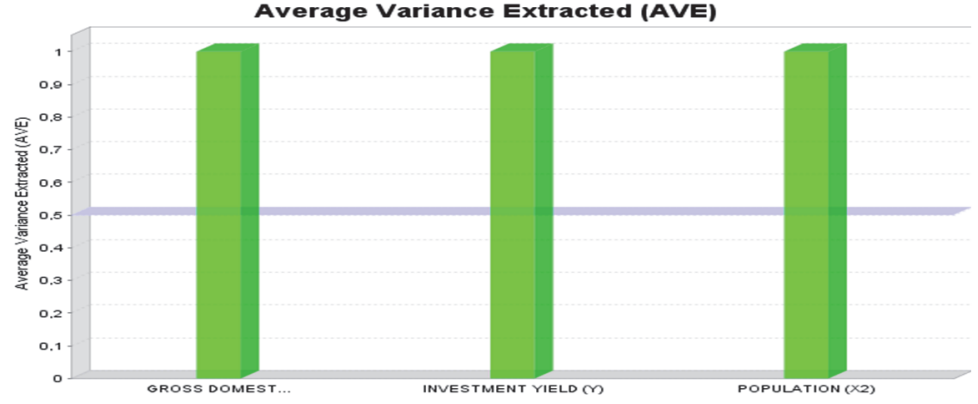

Fig. 5. The average variance extracted (AVE) values Sources : SmartPLS result (2018).

Based on Fig. 5. the population bar graph diagram, the figure is higher than the gross domestic product (GDP) showing that the variable is significant and is in accordance with the results of the calculation of the significance parameters. The average variance extracted (AVE) value in Fig. 5 measures the amount of variance that can be captured by the construct compared to the variance caused by the measurement error. AVE values must be greater than 0.5. This is illustrated in Fig. 5. Based on Fig. 6, the average variance extracted (AVE) meaning expects an AVE value $>0.5$. The AVE value is between $0-1$. If the AVE value $=1$. This indicates that the indicator has the magnitude of the variant contained in the construct that is perfect. An AVE value $=1$ occurs in constructs that have only one indicator.

\subsection{Discussion}

Activities covered by the trade subsector include both buying and selling goods and can be grouped into two types of activities. i.e., wholesalers and retailers (Keren. 1997). The financial sub-sector consists of banks as well as insurance services, pension funds, mortgages and financing institutions as a promising field that are adequate for shareholders (Saad, 1995; Medani, 1997; ElGamal, 2006; Aisyah, 2018; Mihajat \& Iman, 2018; Samad, 2018; Shaban \& James, 2018; Gree, 2019; Styhre, 2020). The rental sub-sector includes the leasing of buildings and land, including those concerning residential and non-residential buildings, such as offices and ground rental businesses. There are the general and defense sub-sectors of the government as well as the private sub-sector. Government services are principally divided into two, namely the first ministry of the ministry and defense, and the services provided by the bodies under the department, while the second service is called other government services. The private sub-sector consists of social services, and entertainment and recreation services, as well as personal and household services (Bruner, 2018). The service sub-sector of the company consists of legal services accounting services, processing services and data entry services, building services, architects and engineering, advertising services, and marketing research and rental services. The level of welfare of a country's population can be measured by looking at the increase in real income per capita. Real income per capita is calculated from the overall real national income generated during the year divided by the total population. The level of population welfare will be achieved if the national real income increases faster than the population growth. There are two factors that can affect the high and low real income of a country, namely population and labor. When viewed from its role, there are two important roles of the population in increasing the economic development outcomes of a country, namely (1) residents act as consumers in terms of demand and (2) residents act as producers in terms of supply. The development of the population is not 
always an obstacle to economic growth. provided that this population has a high capacity to produce and absorb the resulting production. This means that the high population growth must be accompanied by high levels of income. High population growth with low-income levels will have no meaning for economic growth in a country. The investment climate reflects a number of factors related to opportunities and incentives for capital owners to conduct business or investment productively and develop or a business climate that encourages someone to invest at the lowest possible cost and risk and produce the highest possible long-term profits. In economic and business activities. there are various types of risks that must be addressed. As an effort to tackle risk and at the same time constitute one of the community funds raising institutions as takaful (sharia insurance), the insurance business has a strategic position in the business and economic life of the country in an effort to create prosperity (Demertzis \& Zenios, 2018; Ismant, 2018; Kuldashev, 2018; Ngwu et al., 2018; Porter \& Kramer, 2019; Hiam-Galvez et al., 2020). As an institution that collects funds belonging to the community that must run their business by referring to sound and responsible business principles, the insurance business is a business sector that must be subject to government regulation. The "spin off policy" is a form of regulation policy (Wulandari et al., 2018; Rasmussen et al., 2020). The aim of the spin-off policy is that the management of Islamic insurance can be conducted more independently than when managed by the sharia unit in the insurance company. With the spin-off policy, it is expected that insurance companies can pay more attention to their sharia units. The spin-off encourages the independence of the management of the sharia unit organization, which indeed should be independent. However, if regulations are implemented, Islamic insurance in Indonesia faces a problem. namely independence. Before the spin-off policy, most sharia insurance still experienced a dependency between the subsidiaries resulting from the spin-off of the parent. In addition, there is still a large influence of the parent on the spin-off entity. After the spin-off, the parent can fully release its subsidiary entity and otherwise, the subsidiary must have the courage to act independently without expecting management and advice from the parent of the sharia insurance company.

\section{Conclusions}

The Gross Domestic Product did not influence the investment yield; however, the population did influence the investment yield of sharia insurance in Indonesia. In addition, there is an implication to support the Indonesian monetary policy authorities to anticipate the monetary policy by the Fed, regarding dovish and hawkish sentiments, to encourage Capital Inflows to emerging countries as this can impact the development of sharia/Takaful insurance in Indonesia. The social implication is that the sharia insurance industry in Indonesia can develop if the public can enjoy convenience in applying for premiums and is reasonable in disbursing sharia insurance claims. The majority of Indonesia's population of Moslems requires openness in the process. This study took a sample of different sharia industry characteristics from sharia and conventional types of industry. This research method did not consider Fixed Effects and Random Effects Tests. The implications of this study are expected to be recommended to the Indonesia Financial Services Authority regarding the GDP and Population impacts on the investment yield in Indonesia.

\section{References}

Abdi, E. A., \& Cheluget, J. (2018). Relationship between risk management practices and the performance of Islamic financial institutions. Journal of Finance and Accounting, 2(2). 45-59.

Arellano, C., Bai, Y., \& Kehoe, P. J. (2019). Financial frictions and fluctuations in volatility, Journal of Political Economy, 127(5), 2049-2103.

Abdulkader, T., Cox, S., \& Kraty, B. (2005). Structuring Islamic finance transitions. Euromoney Institutional Investor PLC, Dubai.

Abelson, P., \& Dalton, T. (2018). Choosing the Social Discount Rate for Australia. Australian Economic Review, 51(1), 52-67.

Ahmed, A. (2010). Global financial crisis: An Islamic finance perspective, International Journal of Islamic and Middle Eastern Finance and Management, 3(4), 306-320,

Ahmed, E. R., Amran, A., \& Islam, M.A. (2018). Sukuk Documentation and Legitimacy: The Role of Shariah Supervisory Board as a Moderator. Management, 5(3), 22-40.

Aisyah, M., (2018). Islamic bank service quality and its impact on Indonesian customers' satisfaction and loyalty. Al-Iqtishad Journal of Islamic Economics, 10(2), 367-388.

Alam, M. K., Rahman, S. A., Hossain, M. S., \& Hosen, S. (2019). Shariah governance practices and regulatory problems of Islamic insurance companies in Bangladesh, International Journal of Academic Research in Business and Social Sciences, 9(1), 109124.

Albetairi, H.T.A., Kukreja, G., \& Hamdan, A. (2018). Integrated reporting and financial performance: Empirical evidences from Bahraini listed insurance companies. Accounting and Finance Research, 7(3), 102-123.

Alhomaidi, A., Hassan, M, K., Hippler, W, J., \& Mamun, A., (2018). The impact of religious certification on market segmentation and investor recognition. Journal of Corporate Finance, https://doi.org/10.1016/j.jcorpfin.2018.08.012

Alqahtani, F, (2018), Economy Downturn, Islamic Banking and the Indirect Consequences of the Global Financial Crisis, Review of Economics \& Finance, 12(1), 72-87. 
Alshammari, A.A., Alhabshi, S. M. B. S. J., \& Saiti, B. (2018). The impact of competition on cost efficiency of insurance and takaful sectors: Evidence from GCC markets based on the Stochastic Frontier Analysis, Research in International Business and Finance, In Press https://doi.org/10.1016/j.ribaf.2018.09.003

Amron, A., Usman, U., \& Mursid, A. (2018). The role of electronic word of mouth, conventional media, and subjective norms on the intention to purchase Sharia insurance services, Journal of Financial Services Marketing, 8(1), 77-89.

Baber, H., \& Zaruova, C. (2018). Religion and banking: A study of Islamic finance in India. International Journal of Industrial Distribution \& Business, 9(6), 7-13.

Banerjee, R., \& Majumdar, S. (2018). Impact of firm specific and macroeconomic factors on financial performance of the UAE insurance sector. Global Business and Economics Review, 20(2), 248-261.

Barbu, T.C., \& Boitan, I.A. (2018). Immigrants' impact on financial market-European countries' evidence. Zbornik Radova Ekonomski Fakultet u Rijeka, 36(1), 181-210.

Baranowski, P., Doryń, W., Łyziak, T., \& Stanisławska, E. (2020). Words and deeds in managing expectations: empirical evidence on an inflation targeting economy (No, 326), Narodowy Bank Polski, Economic Research Department.

Benlagha, N., \& Hemrit, W. (2018). The Dynamic and Dependence of Takaful and Conventional Stock Return Behaviours: Evidence from the Insurance Industry in Saudi Arabia. Asia-Pacific Financial Markets, 25(4), 285-323.

Bennani, H., Kranz, T., \& Neuenkirch, M. (2018). Disagreement between FOMC members and the Fed's staff: New insights based on a counterfactual interest rate. Journal of Macroeconomics, 58(1), 139-153.

Bonam, D., \& Goy, G. (2019). Home biased expectations and macroeconomic imbalances in a monetary union. Journal of Economic Dynamics and Control, 103, 25-42.

Boakye, M. A. (2018). Corporate Governance and Firm Efficiency in The Long-Term Insurance Market in South Africa, Doctoral dissertation, University of Cape Town.

Bruner, C. M. (2018). How Small Jurisdictions Compete in International Financial Services, In Integration and International Dispute Resolution in Small States (pp, 167-185), Springer, Cham.

Buckle, M., \& Thompson, J. (2020). The UK financial system: Theory and Practice, Manchester University Press.

Clarke, T., \& Gholamshahi, S. (2018). Developing human capital for knowledge based economies, In Innovation in the Asia Pacific (pp, 247-270), Springer, Singapore.

Corbet, S., Dunne, J, J., \& Larkin, C. (2019). Quantitative easing announcements and high-frequency stock market volatility: Evidence from the United States. Research in International Business and Finance, 48, 321-334.

Darwish, S. (2018). Risk management and insurance practices in protecting the GCC economies: Impact of climate change. European Scientific Journal, 14(13), 88-94.

Demertzis, M., \& Zenios, S. (2018). State contingent debt as insurance for euro-area sovereigns. Bruegel Working Paper, 3(26), April 2018.

Dong, B., Ma, X., Wang, N., \& Wei, W. (2020). Impacts of exchange rate volatility and international oil price shock on China's regional economy: A dynamic CGE analysis, Energy Economics, 86, 103762.

Effendi, J. (2018). Islamic insurance: A potential Niche market of Indonesia. Al-Iqtishad, 10(1), $207-230$.

Eklund, M. A. (2019). Compensation According to Risk of the Firm. In Fairness of CEO Compensation (pp, 75-80), Springer, Cham.

El Ouadghiri, I., \& Peillex, J. (2018). Public attention to "Islamic terrorism" and stock market returns. Journal of Comparative Economics, https://doi.org/10.1016/j.jce.2018.07.014

El-Gamal, M. (2006), Islamic finance: Law, economics, and practice Cambridge University Press, Cambridge, U.K.

Elsner, A., Kleinert, T., \& Strebel-Nelson, H. (2018), Islamic Banking 101: Turkish Banks in Germany, In German-Turkish Perspectives on IT and Innovation Management (pp, 333-349), Springer Gabler, Wiesbaden.

Erdoğan, S., Yıldırım, D, Ç., \& Gedikli, A. (2020). Natural resource abundance, financial development and economic growth: An investigation on Next-11 countries. Resources Policy, 65, 101559.

Faisal, S.M., Khan, A.K., \& Al Aboud, O.A, (2018). Estimating Beta ( $\beta$ ) Values of Stocks in the Creation of Diversified PortfolioA Detailed Study. Applied Economics and Finance, 5(3), 89-99.

Financial Services Authority Indonesia.(2017), Annual Report 2016-2017, Republic of Indonesia, Jakarta.

Fonta, W.M., Sanfo, S., Kedir, A.M., \& Thiam, D.R. (2018), Estimating farmers' willingness to pay for weather index-based crop insurance uptake in West Africa: Insight from a pilot initiative in Southwestern Burkina Faso. Agricultural and Food Economics, 6(1), 11-25.

Green, W. N. (2019). From rice fields to financial assets: Valuing land for microfinance in Cambodia. Transactions of the Institute of British Geographers, 44(4), 749-762.

Hasyim, F. (2018). The determinant of takaful acceptance: Theory of reasoned action approach. Journal of Finance and Islamic Banking, 1(1), 45-57.

Hiam-Galvez, D., Prescott, F., \& Hiam, J. (2020). Designing Sustainable Prosperity "DSP”: A collaborative effort to build resilience in mining producing regions. CIM Journal, 11(1), 69-79.

Ismanto, K. (2018). Understanding on and Need for Syaria Insurance: A Case Study in Pekalongan, Central Java, Indonesia", Journal of Accounting and Investment, 19(2), 137-148. 
Jiang, Y. (2018). Islamic Financial Development and cooperation among Member States in CICA. Asian Journal of Middle Eastern and Islamic Studies, 12(2), 155-166.

Kail, E.M., \& Meriam, A.A.Z.I. (2018). Creation of an Islamic stock market index on the Casablanca finance city (Moroccan All Shares Index-MASI). Revue du Contrôle de la Comptabilité et de l'Audit, 4(4).76-89.

Karen, P. (1997). Is there an Islamic Economics?', in Joel Beinin and Joe Stork, Political Islam: Essays from Middle East Report, University of California Press, California.

Karim Consulting Indonesia, (2017). Islamic Insurance Outlook 2017, Jakarta.

Kesa, D.D. (2018). Bancassurance and the consumers' perspective on bank service quality. KnE Social Sciences, 3(11), 11421155.

Keenan, J, M., Chu, E., \& Peterson, J. (2019). From funding to financing: perspectives shaping a research agenda for investment in urban climate adaptation. International Journal of Urban Sustainable Development, 11(3), 297-308.

Medani, K. (1997). Funding Fundamentalism: The Political Economy of an Islamist State', in Joel Beinin and Joe Stork, Political Islam: Essays from Middle East Report, University of California Press, pp, 169.

Koswara, A. (2018). Differences in Takaful vs conventional insurance in the table, Retrieved from http://syariahx.blogspot.com/2018/01/perbedaan-asuransi-syariah-vs-konvensional.html, (accessed 20 November 2018).

Kuldashev, K.M. (2018). Insurance market of Uzbekistan and need for mutual insurance companies. Digest Finance, 23(2), 246259.

Lian, W., Novta, N., Pugacheva, E., Timmer, Y., \& Topalova, P. (2020). The price of capital goods: a driver of investment under threat. IMF Economic Review, 68(3), 509-549.

Mihajat, S., \& Iman, M. (2018). Shari'a governance framework in Islamic banking in Oman: Issues and challenges. Journal of Islamic Banking \& Finance, 35(3), 124-139.

Mishra, P., N'Diaye, P., \& Nguyen, L. (2018). Effects of fed announcements on emerging markets: What determines financial market reactions?, IMF Economic Review, pp.1-31,

Muda, I., Siregar, H. S., Sembiring, S. A., Manurung, H., \& Zein, Z. (2018). Economic Value of Palm Plantation in North Sumatera and Contribution to Product Domestic Regional Bruto.

Motsepe, M. (2018). An Industry Level Analysis of Demand for Insurance in South Africa. Doctoral dissertation, University of Cape Town.

Mroueh, M., \& de Waal, A. (2018). Is the high performance organization framework applicable to Takaful insurance companies?. Journal of Islamic Accounting and Business Research, 9(1).77-90.

Ngwu, F, N., Ogbechie, C, I., \& Atanya, O. I. (2018). Insurance 2 penetration in Sub-Saharan Africa. The Service Sector and Economic Development in Africa, 11(1), 234-246.

Park, H., \& Kim, J. D. (2020). Transition towards green banking: role of financial regulators and financial institutions, Asian Journal of Sustainability and Social Responsibility, 5(1), 1-25.

Panagopoulos, A, G., Chatzigagios, T., \& Dokas, I. (2018), The global single and regulated market framework of financial products and the international economic policies: Mathematical approach of the model. International Journal of Financial Research, 9(2), 1-15.

Panorama, M, (2018). Measuring regional Islamic bank efficiency in Indonesia. KnE Social Sciences, 3(10), $492-507$.

Purwaningrat, P.A. (2018). Efficiency insurance companies in Indonesia, Malaysia and Singapore. Clear International Journal of Research in Commerce \& Management, 9(3), 64-76.

Porter, M. E., \& Kramer, M. R. (2019). Creating shared value, In Managing sustainable business (pp, 323-346), Springer, Dordrecht.

Rasmussen, E., Benneworth, P., \& Gulbrandsen, M. (2020). Motivating universities to support spin-off firms: Stakeholders and start-up incubation ecosystems, In Research Handbook on Start-Up Incubation Ecosystems, Edward Elgar Publishing.

Qoyum, A., Mardiya, M., \& Sakti, M.R.P. (2018), Indonesian Capital Market Efficiency: Islamic vis-a-vis Conventional", Shirkah: Journal of Economics and Business, 2(3), 66-76.

Rethel, L. (2018). Economic governance beyond state and market: Islamic capital markets in Southeast Asia, Journal of Contemporary Asia, 48(2), 301-321.

Reyna, A. M., \& Fuentes, H. J. (2018), A cost efficiency analysis of the insurance industry in Mexico. Journal of Productivity Analysis, 49(1), 49-56.

Saad, A. (1995), The Islamic Stock Exchange, in Saad Al-Harran (ed.), Leading Issues in Islamic Banking and Finance, Pelanduk Publications, Selangor, Malaysia.

Samad, A. (2018). Is there any causality between Islamic banks' return on depositors and conventional banks' deposit interest? Evidence of causality from Bahrain's financial market. Business and Economic Horizons, 14(4), 894-912.

Savitska, S., Zaika, S., Svystun, L., Koval, L., \& Haibura, Y. (2020). Investment providing sustainable development of rural areas in Ukraine. Independent Journal of Management \& Production, 11(8), 571-586.

Shaban, M., \& James, G.A. (2018). The effects of ownership change on bank performance and risk exposure: Evidence from Indonesia. Journal of Banking \& Finance, 88, 483-497. 
Shileche, E. A., Weke, P., \& Achia, T. (2020). Kernel density estimation of white noise for non-diversifiable risk in decision making. Journal of Risk Analysis and Crisis Response, 10(1), 6-11.

Shah, S. A.A., Javeria, K., \& Masood, O. (2018). Consumption of Family Takaful affected by Microeconomic Factors: A Case Study of Islamic insurance Takaful in Pakistan, European Journal of Islamic Finance, 17(9), 85-97.

Shaikh, S.A. (2018). Role of Islamic banking in financial inclusiveness in Pakistan: promise, performance and prospects. International Journal of Financial Services Management, 9(1), 88-102.

Shetty, A., \& Basri, S. (2018). Assessing the technical efficiency of traditional and corporate agents in Indian Life Insurance Industry: Slack-based data envelopment analysis approach. Global Business Review, 0972150917749.

Sinha, A. (2018). Performance evaluation of private life insurance industry in India. ASBM Journal of Management, 11(1), 40-59.

Siddiqui, M., \& Yousaf, S. U. (2020). Interpretive analysis of the Sharī ah status of insurance policies, and establishment of the alternative. Al-Qalam, 25(1), 42-54.

Sundh, J., \& Juslin, P. (2018), Compound risk judgment in tasks with both idiosyncratic and systematic risk: The Robust Beauty of additive probability integration, Cognition, 171(1), 25-41.

Suryawati, B.N., \& Unsun-Nidhal, L. (2018). Value at risk as a measurement of market Risk in Emerging Sharia Market:, KnE Social Sciences, 3(5), 94-108.

Suryomurti, W. (2018). Constructing an Islamic socially responsible investment (SRI) index; The case of Indonesia. Tazkia Islamic Finance and Business Review, I(2), 24-37.

Syed, A.S., Ab, Rashid, H.M., \& Htay, S.N.N. (2018). The impact of internal forces on acceptance of Takaful by insurance policyholders in India, Journal of Islamic Accounting and Business Research, (just-accepted), 00-00.

Styhre, A. (2020). Thinly and thickly capitalized projects: Theorizing the role of the finance markets and capital supply in project management studies. Project Management Journal, 51(4), 378-388.

Tarmizi, H.B., Daulay, M., \& Muda, I. (2017). Impact of the economic growth and acquisition of land to the construction cost index in North Sumatera, IOP Conference Series: Materials Science and Engineering, 180, doi: 10.1088/1757$899 X / 180 / 1 / 012004$.

Widodo, A. (2018). Evaluating the effectiveness of dual monetary policy in promoting price stability in Indonesia. Iqtishadia: Journal of Islamic Economics and Business Studies, 10(2), 210-233.

Wulandari, L., Siregar, H., \& Tanjung, H. (2018). Spin off Feasibility Study of Sharia Financing Unit: Study in Adira Finance, Al-Iqtishad Journal of Islamic Economics, 10(2), 299-312.

Yas, M., Aslan, H., \& Ozdemir, M. (2018). Modern History of Islamic Finance and a Strategic Roadmap for Its Development in Turkey, Turkish Economy (pp, 213-238), Palgrave Macmillan, Cham.

Yu, L., Cheng, J., \& Lin, T. (2018). Life insurance lapse behaviour: evidence from China, The Geneva Papers on Risk and Insurance-Issues and Practice, pp.1-26.

Zafar, M, W., Shahbaz, M., Hou, F., \& Sinha, A. (2019). From nonrenewable to renewable energy and its impact on economic growth: the role of research \& development expenditures in Asia-Pacific Economic Cooperation countries, Journal of Cleaner Production, 212, 1166-1178.

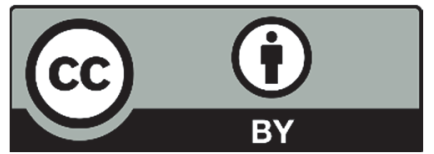

(C) 2021 by the authors; licensee Growing Science, Canada. This is an open access article distributed under the terms and conditions of the Creative Commons Attribution (CC-BY) license (http://creativecommons.org/licenses/by/4.0/). 